\title{
Can ownership structure and board characteristics affect firm performance?
}

\author{
Nisreen Al-Qatanani ${ }^{\mathrm{a}}$ and Youssef Abu Siam ${ }^{\mathrm{a}^{*}}$
}

aAccounting Department, Faculty of Business, Applied Science Private University, Amman, Jordan

\section{H R O N I C L E}

Article history:

Received: November 30, 2020

Received in revised format:

April 32021

Accepted: April 4, 2021

Available online:

April 6, 2021

Keywords:

Jordan

Board characteristics

Family ownership

Firm performance

\section{A B S T R A C T}

This research aimed to examine the association between board of directors' characteristics as a composite measure, the performance of companies in Jordan and the influence of family ownership on this association. Using data on industrial companies indexed on the Amman Stock Exchange (ASE) from 2013 to 2017, a positive association between board characteristics and company performance was found, indicating that higher board effectiveness is associated with more effective monitoring of management behavior. In addition, the association between board characteristics and company performance was strong when there was an interaction with family ownership, as companies with boards with family members achieve higher performance than companies with boards run by external directors. The study findings could be useful to all regulators seeking to improve the quality of monitoring mechanism practices, especially in emerging economies.

(C) 2021 by the authors; licensee Growing Science, Canada

\section{Introduction}

In response to recent economic crises and corporate scandals, a great deal of effort has been made to issue regulations and reforms that could help prevent such crises in the future. For example, corporate governance mechanisms (hereafter CGM) have been developed to improve company performance by regulating overlapping relationships inside and outside the company, defining responsibilities, and protecting the rights of shareholders and other stakeholders (Liu \& Fong, 2010; Zurigat et al., 2016). One of the main factors influencing the performance of a company is its corporate governance practices. Therefore, it is interesting to reflect on how the characteristics of a board of directors, which is one of the most important internal CGM, impact company performance. A board's effectiveness depends on its characteristics, such as board independence, board size, financial expertise, and board meetings. According to Hashim and Amrah (2016), combining board characteristics could increase board effectiveness. Therefore, the present study used a composite measure to try to understand the influence of four board characteristics (board independence, board size, financial expertise, and board meetings) on company performance. Several studies have shown that the efficacy of CGM depends on a company's ownership structure (Desender et al., 2013; Idris et al., 2018b). For example, a board's effectiveness is greatly influenced by the form of ownership of the company (Bennett et al., 2003; Abu Siam et al., 2018). Numerous recent studies have drawn attention to the second (and most prevalent) type of agency problem in which the majority shareholders seek to obtain special incentives and benefits by confiscating the rights of the minority shareholders (Chobpichien et al., 2008). This is an issue of concern in many countries, especially emerging countries, which feature a more centralized ownership structure and poor legal protection for small shareholders (Idris et al., 2018a). In Jordan, which is the focus on the present study, companies have unique characteristics related to ownership structure, and family ownership (FO) is prevalent, especially in industrial and financial companies (Al-Najjar et al., 2010). According to Singh et al.

* Corresponding author. Tel.: +962791048393

E-mail address: yousefabusiam@asu.edu.jo (Y. A. Siam) 
(2018), recent academic research has called for the testing of factors and interrelationships between variables; however, few studies have investigated the influence of moderating or mediating variables (such as concentration of ownership, firm size, and age) on company performance (Guizani, 2013; Kouki \& Guizani, 2015; Singh et al., 2018). The present study responds to Singh et al.'s (2018) call to address this gap, and is one of the rare studies to examine, in the Jordanian context, the effect of FO as a moderate variable on the association between board characteristics as a composite measure and the performance of industrial firms listed on the Amman Stock Exchange (ASE) between 2013 and 2017.

\subsection{Board Characteristics, Family Ownership, and Company Performance}

According to the agency theory, the separation of ownership and control results in a difference of interest between managers and shareholders. For instance, managers might have incentives to serve their own interests instead of maximizing owner wealth; this is known as the first type of agency problem. A board of directors is responsible for mitigating conflicts of interest between the management and owners of a company, and successful mitigation leads to an improvement in the company's efficiency (Chatterjee et al., 2003; Lorca et al., 2011). It is also essential for a board of directors to monitor administrative decisions, which are delegated by shareholders to ensure the protection of their interests and the preparation of reliable and complete financial reports. Furthermore, the preparation of high-quality financial reports enhances investor trust in company performance. Anca (2012) argued that the most vital board characteristics are the board's independence and separation from the executive management, board size, and the incentives granted to the executive management. In addition, prior studies indicated that good CGM enhances company performance by helping the company achieve its goals by increasing profits (Piot et al., 2007; Ertugrul \& Hegde, 2008). Meanwhile, Desender (2009) noted that the corporate ownership structure influences the efficacy of CGM. Companies in emerging countries have the most widespread concentration of ownership and weak legal rights for minority shareholders where the second type of agency problem is prevalent (Omran et al., 2008).

\section{Literature Review and Hypothesis Development}

The senior executive unit of a company is its board of directors, and management is responsible for supervision and oversight as it operates on behalf of the shareholders. Jaafar and El-Shawa (2009) analyzed the impact of the concentration of ownership and board characteristics (board size, multiple board directorships, and CEO duality) on the performance of companies indexed on ASE from 2002 to 2005 . The results indicated that board size and multiple board directorships positively influenced company performance. Meanwhile, Zedan and Abu Nassar (2014) explored the association between CGM and the performance of companies indexed on ASE from 2005 to 2009. The results revealed that company performance was positively affected by CEO duality and board size. Conheady et al. (2015) reported that an efficient board of directors is essential when using agency theory to solve the problem of separating ownership from management in modern companies. The study examined the effect of board effectiveness on company performance in a sample of Canadian companies from 2003 to 2009. The results showed a strong link between board effectiveness and company performance. Meanwhile, Johl et al. (2015) studied the influence of board characteristics (board meetings, board independence, board size, and board members' financial experience) on company performance. The study utilized financial and non-financial data on 700 Malaysian public firms listed in 2009. The findings showed that board independence did not affect company performance, while board size and board members' financial experience were positively linked to company performance. In addition, the study reported a negative association between board meetings and company performance. Singh et al. (2018) analyzed the relationship between board characteristics (board size, board independence, CEO duality, and board committees) and company performance, as measured by Tobin's Q, in 324 companies listed in Pakistan between 2009 and 2015. The study reported that board size and board committees were positively associated with company performance, while board independence and CEO duality were negatively associated with company performance. In addition, Khadash and Washali (2019) identified the effect of diverse board characteristics on the accounting and market performance indicators of all banks and insurance firms indexed on ASE between 2010 and 2015. Specifically, the study examined the effects of gender, nationality, experience, the percentage of board members with a higher education degree, and the percentage of board members with financial certificates on company performance. The study found that gender, nationality, and educational diversity did not have an influence on company performance.

The aforementioned studies may have had contradictory results because they examined the effects of individual board characteristics on company performance (Lorca et al., 2011). This line has been highly criticized in the recent literature on CGM for its lack of coverage of the quality of CGM (Ward et al., 2009; Ishak \& Al-Ebel, 2013). To reduce the costs of agency and protect the interests of all stakeholders, it is better to measure CGM as a composite measure. For instance, Ward et al. (2009) asserted that prior studies had rather divergent findings because they considered individual governance mechanisms in separation when addressing agency problems and ignored the idea that the effectiveness of one mechanism relies on the effectiveness of other mechanisms. Furthermore, the efficacy of CGM relies on firms' and countries' institutional structures, such as ownership structure (Young et al., 2008). Therefore, the following two hypotheses were tested in the present study:

$\mathbf{H}_{1}$ : Board characteristics are related to company performance.

$\mathbf{H}_{2}$ : FO influences the association between board characteristics and company performance. 


\section{Research Methodology}

\subsection{Sample Selection}

The research population included all Jordanian public shareholders indexed on ASE from 2013 to 2017, while the study sample consisted of the 62 industrial firms indexed on ASE during the same period (www.sdc.com.jo).

\subsection{Dependent Variable}

To measure company performance, the present study followed the approach used by Singh et al. (2018) by measuring company performance using the Tobin's Q.

\subsection{Independent Variable}

The present study examined four board characteristics: the independence of the board members, the financial expertise of the board members, board meetings, and board size. To measure the board characteristics as a composite measure (BC-Score), the study compared the average value of each variable with each value of that variable, and then the scores for the four individual board characteristics were combined to create a comprehensive board characteristics scale from 0 to 4 (Hashim \& Amrah, 2016).

\section{Regression Models}

The research hypotheses were tested using two regression models. The first model was used to determine the association between $\mathrm{BC}$-Score and company performance. The second model was used to measure the influence of FO on the association between $\mathrm{BC}$-Score and company performance by including a term of interaction between BC-Score and FO.

Model (1): $C P_{i t}=a_{0}+\beta_{1} S_{i t}+\beta_{2} B I G 4_{i t}+\beta_{3} B C-$ Score $_{i t}+\varepsilon_{i t}$

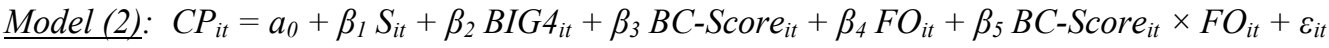

Table 1 shows the definitions of the study variables used in these models.

Table 1

Measurements of the Variables

\begin{tabular}{|c|c|c|}
\hline Variables & $\underline{\text { Symbol }}$ & Measurement \\
\hline \multicolumn{3}{|r|}{ Dependent Variable } \\
\hline $\begin{array}{l}\text { Company Performance } \\
\text { (Tobin's Q) }\end{array}$ & $\mathrm{CP}$ & $\begin{array}{l}\text { By dividing the market value of the firm's shares by the book value of the total firm assets (Singh, et al., } \\
\text { 2018). }\end{array}$ \\
\hline \multicolumn{3}{|r|}{ Independent Variable } \\
\hline $\begin{array}{l}\text { Board Characteristics } \\
\text { Score }\end{array}$ & BC-Score & $\begin{array}{l}\text { The sum of the four board characteristics (independence, financial expertise, meetings, and size). A score of } \\
4 \text { indicates that all four characteristics were above the sample median, while a score of } 0 \text { indicates that all } \\
\text { four characteristics were equal to or lower than the sample (Hashim \& Amrah, 2016). } \\
\text { - Board Independence: The percentage of independent members of the board (Young et al., 2008). } \\
\text { - Board Financial Expertise: The percentage of the members of the board with financial and accounting } \\
\text { experience (Ahmed, 2014). } \\
\text { - Board Meetings: The number of annual board meetings (Xie et al., 2003). } \\
\text { - Board Size: The number of board members (Allegrini \& Greco, 2013). }\end{array}$ \\
\hline \multicolumn{3}{|r|}{ Moderate Variable } \\
\hline Family Ownership & FO & $\begin{array}{l}\text { This variable measured the percentage of family owners on the board of directors compared to the total } \\
\text { number of board members (Yoshikawa \& Rasheed, 2010). }\end{array}$ \\
\hline \multicolumn{3}{|r|}{ Control Variables } \\
\hline Audit Firm Size & BIG 4 & $\begin{array}{l}\text { A score of } 1 \text { was given if one of the Big } 4 \text { companies audited the company; otherwise, a score of } 0 \text { was } \\
\text { given (Inaam \& Khmoussi, 2012). }\end{array}$ \\
\hline Firm Size & $\mathrm{S}$ & The natural logarithm of total assets at the end of the year (Ismail et al., 2009). \\
\hline
\end{tabular}

\section{Methodology and Results}

\subsection{Descriptive Statistics}

As shown in Table 2, the descriptive statistics for the four board characteristics were higher than the statistical average for all studied companies. In addition, for number (3), three of the four characteristics whose value was higher than the average for each of the board's characteristics and so on until the lowest value of (1) that reflects just one out of four characteristics for all companies was above average. The mean value for the BC-Score was 2.94 , with a standard deviation of 0.706 and minimum and maximum values of 0 and 4, respectively. This finding suggests that boards that achieve a higher degree of effectiveness are more successful at resolving conflicts between companies by improving the efficacy of management control and supervision, which, in turn, enhances the efficiency of the company. The mean value for company performance was 0.978 , with a standard deviation of 0.223 , which indicates that company performance was almost reasonable and implies that the replacement value of the assets of a company is similar to the value of its shares (Abweeni \& Al-Omari, 2016). Regarding FO, the maximum was $100 \%$ and the minimum for certain companies was $0 \%$, and the percentage of ownership by board members in the studied 
companies was $22.6 \%$. The mean firm size was 7,225, with a standard deviation of 0.494 and minimum and maximum values of 5,861 and 7,341, respectively. In addition, the average audit firm size (BIG4) was 32\%, with a standard deviation of 0.467 , indicating that the four main audit firms audited $32 \%$ of the companies.

Table 2

Descriptive Statistics

\begin{tabular}{|c|c|c|c|c|}
\hline Variable & Mean & Standard Deviation & Maximum & Minimum \\
\hline $\mathrm{CP}$ & 0.978 & 0.223 & 1.491 & 0.296 \\
\hline BC_Score & 2.940 & 0.706 & 4.000 & 1.000 \\
\hline$\overline{\mathrm{FO}}$ & 0.226 & 0.248 & 1.000 & 0.000 \\
\hline $\mathrm{S}$ & 7.225 & 0.494 & 7.341 & 4.681 \\
\hline BIG4 & 0.032 & 0.467 & 1.000 & 0.000 \\
\hline
\end{tabular}

\subsection{Main Empirical Findings}

Table 3

Regression analysis results of board characteristics, FO and CP

\begin{tabular}{|c|c|c|c|c|}
\hline \multirow{2}{*}{ Variables } & \multicolumn{2}{|c|}{ Model (1) } & \multicolumn{2}{|c|}{ Model (2) } \\
\hline & Cofe. & t-stat & Cofe. & t-stat \\
\hline Intercept & $0.437 *$ & 1.919 & $0.474 * *$ & 2.094 \\
\hline BC_Score & $0.300 * * *$ & 4.396 & $0.288 * * *$ & 4.239 \\
\hline$\overline{\mathrm{FO}}$ & & & $0.044 * *$ & 2.102 \\
\hline BC Score*FO & & & $0.141 * *$ & 2.101 \\
\hline $\mathrm{S}$ & 0.074 & 1.049 & 0.058 & 0.820 \\
\hline BIG4 & 0.067 & 0.967 & 0.080 & 1.151 \\
\hline Adj-R ${ }^{2}$ & 0.082 & & 0.098 & \\
\hline Obs. & 210 & & 210 & \\
\hline F-stat & 3.623 & & 3.777 & \\
\hline
\end{tabular}

$* *, * * *$ and $*$ indicate significant at $1 \%, 5 \%$ and $10 \%$ respectively.

BC_Score*FO $=$ Interaction between board characteristics and FO.

The findings shown in Table 3 indicate that the impact of board characteristics as a composite measure was positive for the performance of industrial companies in Jordan. The results of this study are in line with those of previous studies, suggesting that a board of directors is an important internal control mechanism for monitoring company performance. Thus, an efficient board of directors can mitigate conflicts of interest (agency problems), which, in turn, enhances monitoring effectiveness and improves company performance (Conheady et al., 2015). In addition, the effectiveness of the board plays a critical role in safeguarding the interests of the various stakeholders against the self-interest of management. The literature has indicated that effective board oversight helps maintain financial reporting reliability. Thus, it is rational to assume that an effective board of directors will help improve company performance and reduce the management of earnings (Sarkar et al., 2008). It can be argued that a lack of appropriate supervision by the board of directors or any weakness in the board of directors will encourage management to engage in earnings management practices. As such, agency theory notes that certain essential features of a board of directors, such as independent members, a sufficient board size, regular meetings, and members with financial and accounting skills, would help the board perform its duties more effectively (Cai et al., 2008). The findings shown in Table 3 also illustrate the significant impact of FO as a moderate variable on the association between board characteristics as a composite measure and the performance of industrial companies in Jordan. The results of this study indicate that the presence of FO improves the relationship between the board of directors' effectiveness and company performance. A probable clarification for this result is that board members who are part of the family that owns the company may work hard to maintain their interests and the continuity of their business. However, the agency theory suggests that family managers can share their opinions in several ways because of the multiple lines of contact available between family members; these lines are also advantages in monitoring the work of managers (Fama \& Jensen, 1983; Bartholomeusz \& Tanewski, 2006). Furthermore, the presence of family owners on a board may reduce the agency costs because those members are more knowledgeable about the company's matters and may lead to better monitoring of the company's managers and reduce their opportunistic behavior to maximize their wealth. This idea is consistent with Kang's (1999) argument that the inclusion of family owners on a board of directors leads to good supervision of the managers and that the flow of knowledge between family members and managers can be controlled via meetings with each other. Anderson and Reeb (2004) considered a board of directors composed of family members and independent members to be more effective than a board composed of external directors, primarily because family members feel like they have more knowledge about their business. As a result, family members have more loyalty to the corporation than outsiders because they think of their business as part of their properties (Chen et al., 2011). In addition, a company with a board of directors with family members can achieve higher performance than a company with a board run by outside executives. Further, FO creates better value, particularly if the founder is the CEO of the family business or the chairman of the hired CEO (Villalonga \& Amit, 2006; Amran, 2010). 
The present study aimed to investigate the influence of board characteristics (independence, financial expertise, board meetings, and size) as a composite measure capturing the combined impact of these characteristics on company performance. In addition, FO was studied as a moderate variable on the association between board characteristics as a composite measure and company performance in Jordan. This research expands the scope of earlier studies of company performance by looking at the business environment in Jordan, which is characterized by still weak financial markets and systems. Moreover, companies in Jordan have a highly central ownership structure, and FO is very common. The study findings indicated the positive and important effect of board characteristics as a composite measure of company performance. The study also indicated that FO has a beneficial impact on the relationship between board characteristics and company performance and that companies with boards that include family members achieve better performance than boards run by external managers. In addition to regulators and policy makers in Jordan, the findings of this research can be useful to all stakeholders as they illustrate a range of issues that can be used to help evaluate the effect of CGM on company performance in Jordan. However, this research has some limitations. First, the quality of the tests can be assessed according to the quality of the sample data. Second, since this study only examined industrial firms listed on ASE and did not examine service and financial companies, the validity of the results may not extend to the latter companies. Finally, future research could examine the effectiveness of CGM and corporate performance in various environments using different economic cycles, different financial markets, different periods of time, and/or different sample sizes.

\section{References}

Abu Siam, Y., Idris, M., \& Al-Okdeh, S. (2018). The Moderating Role of Family Control on the Relationship between Audit Committee Financial Expertise and Earnings Management. International Journal of Business and Management, 13(12), 3137.

Abweeni, H., M. \& Al-Omari, A. (2016). The Impact of Corporate Governance and Financial Leverage on Value of Firms Listed on Amman Stock Exchange. Jordan Journal of Business Administration, 12(2), 899 -917.

Ahmed, S. (2014). Board of director characteristics and earnings management in Malaysia. GSTF Journal on Business Review (GBR), 2(4).

Allegrini, M., \& Greco, G. (2013). Corporate Boards, Audit Committees and Voluntary Disclosure: Evidence from Italian Listed Companies. Journal of Management and Governance, 17(1), 187-216.

Al-Najjar, B. (2010). Corporate Governance and Institutional Ownership: Evidence from Jordan. Corporate Governance, 10(2), 176-190.

Amman Stock Exchange 2014. Retrieved from: http://www.ase.com.jo/en/about-ase.

Amran, A., Ishak, M. S., Zulkafli, A. H., \& Nejati, M. (2010). Board structure and extent of corporate governance statement. International Journal of Managerial and Financial Accounting, 2(4), 383-400.

Anca, P., (2012). Corporate Governance: Principles and Regulations, Journal of Electrical \& Electronics Engineering, 5(1), 155-158.

Anderson, R., \& Reeb, D. (2004). Board Composition: Balancing Family Influence in S\&P 500 Firms. Administrative Science, 49(2), 209-237.

Bartholomeusz, S., \& Tanewski, G. (2006). The relation between family firms and corporate governance. Journal of Small Business Management, 44(2), 245-267.

Bennett, J. A., Sias, R. W., \& Starks, L. T. (2003). Greener Pastures and the Impact of Dynamic Institutional Preferences. Review of Financial Studies, 16(4), 1203-1238.

Cai, J., Liu, Y., \& Qian, Y. (2008). Information Asymmetry and Corporate Governance. Drexel College of Business Research Paper No. 2008-02. Retrieved from SSRN website: http://papers.ssrn.com/sol3/papers.cfm?abstract_id=1082589.

Desender, K., A. (2009). The Relationship between the Ownership Structure and Board Effectiveness. University of Illinois at Urbana-Champaign, College of Business Working Papers, pp. 09-0105.

Desender, K. A., Aguilera, R. V., Crespi, R., \& Garcĺa-cestona, M. (2013). When Does Ownership Matter? Board Characteristics and Behavior. Strategic Management Journal, 34(7), 823-842.

Chatterjee, S., Harrison, J., \& Bergh, D. (2003). Failed Takeover Attempts, Corporate Governance and Refocusing. Strategic Management Journal, 24(1), 87-96.

Chen, F., Hope, O.-K., Li, Q., \& Wang, X. (2011). Financial reporting quality and investment efficiency of private firms in emerging market. The Accounting Review, 86(4), 1255-1288.

Chobpichien, J., Haron, H., \& Ibrahim, D. (2008). The Quality of Board of Directors, Ownership Structure and Level of Voluntary Disclosure of Listed Companies in Thailand. Euro Asia Journal of Management, 3(17), 3-39.

Conheady, B., McIlkenny, P., Opong, K. K., \& Pignatel, I. (2015). Board effectiveness and firm performance of Canadian listed firms. The British Accounting Review, 47(3), 290-303.

Ertugrul, M., \& Hegde, S. (2008). Board compensation practices and agency costs of debt. Journal of Corporate Finance, 1(5), 512-531.

Fama, E. F., \& Jensen, M., C. (1983). Separation of ownership and control. The Journal of Law \& Economics, 26(2), 301-325. 
Guizani, M. (2013). The moderating effect of large shareholders on board structure-firm performance relationship: an agency perspective, Journal of Poverty, Investment and Development- An Open Access International Journal, 2, 64-73.

Hashim, H. A., \& Amrah, M. (2016). Corporate governance mechanisms and cost of debt, Managerial Auditing Journal, 31(3), pp. 314-336.

Idris, M., Siam, Y. A., \& Nassar, M. (2018a). Board independence, earnings management and the moderating effect of family ownership in Jordan. Management \& Marketing. Challenges for the Knowledge Society, 13(2), 985-994.

Idris, M. I., Siam, Y. I. A., \& Ahmad, A. L. (2018b). The impact of external auditor size on the relationship between audit committee effectiveness and earnings management. Investment Management and Financial Innovations, $15(3), 122-130$.

Inaam, Z., Khmoussi, H., \& Fatma, Z. (2012). Audit Quality and Earnings Management in the Tunisian Context. International Journal of Accounting and Financial Reporting, 2(2), 17.

Ishak, Z., \& Al-Ebel, A. (2013). Board of Directors, Information Asymmetry, and Intellectual Capital Disclosure among Banks in Gulf Co- Operation Council. Jurnal Pengurusan, 37, 33-43.

Ismail, H., Mohd Iskandar, T., \& Rahmat, M. M. (2009). Corporate Reporting Quality, Audit Committee and Quality of Audit. Malaysian Accounting Review, 7(1), 21-42.

Jaafar, A., \& El-Shawa, M. (2009). Ownership concentration, board characteristics and performance: evidence from Jordan. Research in Accounting in Emerging Economies, 9, 73-95.

Johl, S. K., Kaur, S., \& Cooper, B. J. (2015). Board characteristics and firm performance: Evidence from Malaysian public listed firms. Journal of Economics, Business and Management, 3(2), 239-243.

Kang, D. L., \& Sørensen, A., B. (1999). Ownership organization and firm performance. Annual Review of Sociology, 25(1), 121-144.

Khadash, M. k., \& Washali A., (2019). Board Diversity and Its Impact on Corporate Performance of Public Companies Listed in Amman Stock Exchange: The Case of Banks and Insurance Companies. Jordan Journal of Business Administration, 15(4), $467-487$.

Kouki, M. and M. Guizani (2015). Outside directors and firm performance: the moderating effects of ownership and board leadership structure. International Business Research, 8, 104-116.

Liu, H., \& Fong, M. W. (2010). Board characteristics of medium and large Chinese companies. Corporate Governance the International Journal of Business in Society, 10(2), 163-175.

Lorca, C., Sanchez-Ballesta, J., \& Garcia-Meca, E. (2011). Board Effectiveness and Cost of Debt. Journal of Business Ethics, 100(4), 613-631.

Omran, M. M., Bolbolc, A., \& Fatheldin, A. (2008). Corporate Governance and Firm Performance in Arab Equity Markets: Does Ownership Concentration Matter? International Review of Law and Economics, 28(1), 32-45.

Piot, C., Missonier, R., \& Piera, F. (2007). Corporate governance, audit quality and the cost of debt financing of French listed companies. Working Paper.

Sarkar, J., Sarkar, S., \& Sen, K. (2008). Board of directors and opportunistic earnings management: Evidence from India. Journal of Accounting, Auditing \& Finance, 23(4), 517-551.

Singh, S., Tabassum, N., Darwish, T. K., \& Batsakis, G. (2018). Corporate governance and Tobin's Q as a measure of organizational performance. British Journal of Management, 29(1), 171-190.

Villalonga, B., \& Amit, R. (2006). How do family ownership, control and management affect firm value? Journal of Financial Economics, 80(2), 385-417.

Ward, A. J., Brown, J. A., \& Rodriguez, D. (2009). Governance Bundles, Firm Performance, and the Substitutability and Complementarily of Governance Mechanisms. Corporate Governance: An International Review, 17(5), 646-660.

Xie, B., Davidson III, W. N., \& Da-Dalt, P. J. (2003). Earnings Management and Corporate Governance: The Role of the Board and the Audit Committee. Journal of Corporate Finance, 9(3), 295-316.

Yoshikawa, T., \& Rasheed, A. A. (2010). Family Control and Ownership Monitoring in Family Controlled Firms in Japan. Journal of Management Studies, 47(2), 274-295.

Young, M., Peng, M., Ahlstrom, D., Bruton, G., \& Jiang, Y. (2008). Corporate Governance in Emerging Economies: A review of the Principal-Principal Perspective. Journal of Management Studies, 45(1), 196-220.

Zedan, H. I., \& Abu Nassar, M. H. (2014). The Effect of Corporate Governance on Operating Performance of Jordanian Manufacturing Companies: Evidence from Amman Stock Exchange. Dirasat: Administrative Sciences, 41(2), $465-481$.

Zurigat, Z., Al-Gharibeh M., \& Haddad L. (2016). Agency costs and corporate governance mechanisms, evidence from industrial Jordanian firms listed on the Amman Stock Exchange. Jordan Journal of Business Administration, 12 (2), 307 329.

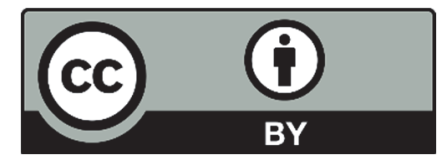

(C) 2021 by the authors; licensee Growing Science, Canada. This is an open access article distributed under the terms and conditions of the Creative Commons Attribution (CC-BY) license (http://creativecommons.org/licenses/by/4.0/). 